Article

\title{
Evaluation of Aphicidal Effect of Essential Oils and Their Synergistic Effect against Myzus persicae (Sulzer) (Hemiptera: Aphididae)
}

\author{
Qasim Ahmed ${ }^{1,+}\left(\mathbb{D}\right.$, Manjree Agarwal $^{2,+}\left(\mathbb{D}\right.$, Ruaa Al-Obaidi $^{3}$, Penghao Wang ${ }^{2, *}$ and Yonglin Ren ${ }^{2, *}(\mathbb{C}$ \\ 1 Agricultural Engineering Sciences, University of Baghdad, Al-Jadriya Campus, Baghdad 10071, Iraq; \\ qasim.h@coagri.uobaghdad.edu.iq \\ 2 College of Science, Health, Engineering and Education, Murdoch University, South Street, \\ Murdoch, WA 6150, Australia; m.agarwal@murdoch.edu.au \\ 3 Pharmacy College, Mustansiriyah University, Al-Qadisyia, Baghdad 10052, Iraq; ruaaloli@gmail.com \\ * Correspondence: p.wang@murdoch.edu.au (P.W.); y.ren@murdoch.edu.au (Y.R.) \\ + These authors contributed equally to this paper.
}

check for

updates

Citation: Ahmed, Q.; Agarwal, M.; Al-Obaidi, R.; Wang, P.; Ren, Y.

Evaluation of Aphicidal Effect of

Essential Oils and Their Synergistic

Effect against Myzus persicae (Sulzer) (Hemiptera: Aphididae). Molecules 2021, 26, 3055. https://doi.org/ $10.3390 /$ molecules 26103055

Academic Editors: Marcello Iriti and Md. Moshfekus Saleh-E-In

Received: 15 March 2021

Accepted: 16 May 2021

Published: 20 May 2021

Publisher's Note: MDPI stays neutral with regard to jurisdictional claims in published maps and institutional affiliations.

Copyright: (c) 2021 by the authors. Licensee MDPI, Basel, Switzerland. This article is an open access article distributed under the terms and conditions of the Creative Commons Attribution (CC BY) license (https:// creativecommons.org/licenses/by/ $4.0 /)$.

\begin{abstract}
The insecticidal activities of essential oils obtained from black pepper, eucalyptus, rosemary, and tea tree and their binary combinations were investigated against the green peach aphid, Myzus persicae (Aphididae: Hemiptera), under laboratory and glasshouse conditions. All the tested essential oils significantly reduced and controlled the green peach aphid population and caused higher mortality. In this study, black pepper and tea tree pure essential oils were found to be an effective insecticide, with $80 \%$ mortality when used through contact application. However, for combinations of essential oils from black pepper + tea tree (BT) and rosemary + tea tree (RT) tested as contact treatment, the mortality was $98.33 \%$. The essential oil combinations exhibited synergistic and additive interactions for insecticidal activities. The combination of black pepper + tea tree, eucalyptus + tea tree (ET), and tea tree + rosemary showed enhanced activity, with synergy rates of 3.24, 2.65, and 2.74, respectively. Essential oils formulation was effective on the mortality of aphids. Fourier Transform Infrared Spectroscopy (FTIR) analysis showed that stability of a mixture of essential oils was not affected by store temperature $\left(15,25\right.$, and $\left.35^{\circ} \mathrm{C}\right)$ and the functional groups were not changed during storage. Based on our results, the essential oils can be used as a commercial insecticide against $M$. persicae.
\end{abstract}

Keywords: aphids; Myzus persicae essential oils; synergistic activity; mortality of aphids

\section{Introduction}

Green peach aphid (GPA) or peach-potato aphid Myzus persicae (Sulzer) belongs to the family Aphididae in the order Hemiptera. This species is considered a polyphagous species that can be found worldwide and globally distributed. The GPA has been reported to feed on more than 500 species of plants from 40 plant families and is considered a major pest of many vegetable crops and plant families such as cucurbits, legumes, crucifers like cabbage, cauliflower, and broccoli, and solanaceous crops like potato, tomato, and capsicum. In addition, fruit crops such as peach trees, for example, serve as M. persicae hosts [1-3]. GPA damage comes from their feeding on plant sap, which causes yellowing and leaf curling of the plant. In addition, M. persicae has been involved in transmitting over 180 plant viruses. Hence, GPA, with a large host range exceeding 50 families of plants, is considered one of the most polyphagous aphids [1,4].

Plant-based biopesticides possessing insecticidal activities belonging to 60 families and showing promise as new botanical pesticides were reviewed and reported in several species of plants $[5,6]$. Most of the botanical pesticides have low to reasonable environmental toxicity, but there are exceptions, such as nicotine, and essential oils may degrade more 
rapidly in the environment than synthetic chemicals [7,8]. Many essential oils have caused high mortality of pests, were shown to be effective by use in different applications such as fumigation, and had antifeedant and repellent properties [9]. Moreover, some essential oils, such as cumin, anise, oregano and eucalyptus essential oils, showed aphicidal activity [10].

Black pepper Piper nigrum L. extracts showed insecticidal activities because they contain isobutyl amides that are toxic to insects. As reported in previous studies, piper extracts are a unique and valuable source of biopesticide [11,12], suitable for controlling small insects and reducing the development of pest resistance when mixed as a synergist with other botanical pesticides such as pyrethrum. It has been shown that black pepper essential oil reduces the adult emergence of cowpea weevil Callosobruchus maculatus by $100 \%$ after 30 days of treatment [13]. Furthermore, rosemary Rosmarinus officinalis essential oil has been used conventionally as a medication in many countries because it is non-toxic to humans and environments [14]. Moreover, it was reported that the effect of $1 \%$ rosemary oil on two-spotted mites Tetranychus urticae for contact toxicity on tomato caused high mortality after using the tomato leaf disc test for 12 and $48 \mathrm{~h}$ [14]. Rosemary essential oil was commercialized as a pesticide for its efficacy against several insect and mite pests; chemical compositions of rosemary oil have shown the $\mathrm{LD}_{50}$ values of the oil ranged from 58.9-335.9 $\mu \mathrm{g} /$ larva when applied to cabbage loopers Trichoplusia ni, and the $\mathrm{LD}_{50}$ values ranged 167.1-372.1 $\mu \mathrm{g} /$ larva for the fall armyworms Pseudaletia unipuncta [15-17]. Moreover, eucalyptus essential oil possesses a wide range of pesticide properties including insecticidal, insect repellent, herbicidal, acaricidal, fungicidal, and anti-microbial, and is considered non-polluting and environmentally friendly with little or no toxicological effect $[2,18]$. Eucalyptus essential oil has insecticidal properties in various forms such as contact, antifeeding, oviposition inhibition, repellence, and fumigant. Eucalyptus leaf extract is effective against aphids by the contact test method and antifeeding; it is effective against cotton leafhopper and cotton stainer by inhibiting oviposition. The fumigant of eucalyptus oil works against houseflies; and the oil and dry powder extract are used to protect potatoes against potato tuber moth [18,19]. In addition, tea tree Melaleuca alternifolia essential oil has been used as insect control agents because it contains bioactive chemicals that are toxic to several insect species, and researchers $[20,21]$ have indicated that M. alternifolia may provide a new and safe alternative to chemical pesticides $[15,20,21]$. Many essential oils including tea tree oil have been examined on several hemipterans (aphids, thrips, whiteflies, and mealybugs) [22,23].

Essential oils represent a green alternative in agricultural fields due to reported insecticidal properties. Essential oils can be degraded by external factors such as temperature, light, and humidity. They have been analyzed by infrared spectroscopic techniques to discriminate function groups among different essential oils during storage [24].

This study was carried out to evaluate the insecticidal activities of essential oils against GPA M. persicae by studying contact toxicity and the synergistic activities of black pepper, tea tree, blue eucalyptus and rosemary essential oils because some pesticides are losing their effectiveness as a result of pest resistance. In addition, it evaluates a synergistic interaction between binary mixtures of essential oils against $M$. persicae in different methods of application. Fourier Transform Infrared Spectroscopy (FTIR) analysis was done to check the stability of essential oil mixtures during storage at different temperatures.

\section{Results}

\subsection{Chemical Composition of Essential Oils}

GC-MS analysis (Table 1) of black pepper (B), eucalyptus (E), rosemary (R), and tea tree (T) essential oils indicated that there are many major constituents in all the types of essential oils (pure and mixture): black pepper contained $\alpha$-Pinene $12.66 \%$, Sabinene $8.6 \%$, $\beta$-Pinene $12.17 \%, 1 \mathrm{R}$ - $\alpha$-Pinene $5.56 \%$, D-Limonene $15.52 \%$, Eucalyptol $3.21 \%$, and Caryophyllene $24.56 \%$, which were the most abundant compounds. The percentages of compounds in eucalyptus oil were P-Cymene 4.82\%, D-Limonene 5.72\%, and Eucalyptol 82.25\%; whereas the main compounds in rosemary oil were $\alpha$-Pinene $15.87 \%$, Camphene $3.89 \%$, 
$\beta$-Pinene 8.5\%, P-Cymene 2.73\%, D-Limonene 3.37\%, Eucalyptol 35.27\%, (-)-Camphor $10.43 \%$, and Caryophyllene $4.92 \%$. The proportions of tea tree chemical composition were (+)-4-Carene 7.31\%, P-Cymene 3.8\%, Eucalyptol 4.98\%, $\gamma$-Terpinene $17.74 \%$, Terpinolene $2.78 \%$, (-)-Terpinen-4-ol 43.94\%, and $\alpha$-Terpineol 3.61\%. However, the most abundant compounds in six types of essential oil combinations (black pepper + eucalyptus (BE), black pepper + rosemary (BR), black pepper + tea tree (BT), eucalyptus + rosemary (ER), eucalyptus + tea tree (ET), and tea tree + rosemary (TR)) were $\alpha$-Pinene 6.76, 14.60, 7.95, $8.28,1.59$, and $9.28 \%$ found in BE, BR, BT, ER, ET, and TR, respectively. Camphene 0.23, $2.32,0.25,1.97$, and $2.00 \%$ for BE, BR, BT, ER, and TR, respectively, with $1 \mathrm{R}-\alpha$-Pinene 2.62 , $2.60,2.85 \%$ found in BE, BR, and BT, respectively. Furthermore, (+)-4-Carene 3.51, 3.55, and $3.96 \%$ were found in BT, ET, and TR, while Sabinene $4.22,4.27$, and $4.58 \%$ were found in BE, BR, and BT, respectively. $\beta$-Pinene $6.12,10.43,6.75,4.35$, and $4.6 \%$ in BE, BR, BT, ER, and TR, respectively; whereas, P-Cymene 3.07, 1.94, 2.45, 3.81, 4.45, and 3.34\%, and also D-Limonene $10.58,9.34,8.80,4.56,3.60$, and $3.34 \%$ were found in all combination types. In addition, Eucalyptol 44.58, 19.63, 4.16, 59.45, 46.31, and $20.56 \%$ originated in six mixtures, and $\gamma$-Terpinene $8.50,9.5$, and $9.38 \%$ in BT, ET, and TR. The proportions of (-)-Terpinen-4-ol were 20.85, 20.94, and 22.02\% in BT, ET, and TR, and the percentages of Caryophyllene in all combinations were 11.50, 14.62, 13.10, 2.36 and 2.73\% for BE, BR, BT, $\mathrm{ER}$, and TR, respectively.

Table 1. Chemical constituents of pure and mixed essential oils analysis by GC-MS.

\begin{tabular}{|c|c|c|c|c|c|c|c|c|c|c|c|}
\hline \multirow{2}{*}{$\begin{array}{l}\mathrm{RT}^{\mathrm{a}} \\
(\mathrm{min})\end{array}$} & \multirow{2}{*}{ Composition } & \multicolumn{10}{|c|}{ Percentage $(\%)$ of Essential Oil Composition ${ }^{b}$} \\
\hline & & B & E & $\mathbf{R}$ & $\mathbf{T}$ & BE & BR & BT & ER & ET & TR \\
\hline 1.97 & Cyclohexane & 2.89 & 2.72 & 2.56 & 2.80 & 2.92 & 2.57 & 2.83 & 2.59 & 2.48 & 2.87 \\
\hline 5.73 & Tricyclene & - & - & 0.66 & - & - & 0.32 & - & 0.32 & - & 0.34 \\
\hline 5.77 & $\alpha$-Thujene & 0.89 & - & - & 0.76 & 0.49 & 0.51 & 0.91 & - & 0.36 & 0.36 \\
\hline 6.07 & $\alpha$-Pinene & 12.66 & 0.90 & 15.87 & 2.27 & 6.76 & 14.60 & 7.95 & 8.28 & 1.59 & 9.28 \\
\hline 6.54 & $\alpha$-Fenchene & - & - & 0.10 & - & - & - & - & - & - & - \\
\hline 6.60 & Camphene & 0.47 & - & 3.89 & - & 0.23 & 2.32 & 0.25 & 1.97 & - & 2.00 \\
\hline 7.38 & Sabinene & 8.60 & - & 0.18 & - & 4.22 & 4.27 & 4.58 & - & - & 0.10 \\
\hline 7.60 & $\beta$-Pinene & 12.17 & 0.35 & 8.50 & 0.58 & 6.12 & 10.43 & 6.75 & 4.35 & 0.47 & 4.60 \\
\hline 7.94 & $\beta$-Myrcene & 1.00 & 0.44 & 1.47 & 0.55 & 0.73 & 1.26 & 0.81 & 0.95 & 0.50 & 1.02 \\
\hline 8.72 & $\alpha$-Phellandrene & 0.20 & 0.41 & 0.26 & 0.28 & 0.41 & 0.35 & 0.34 & 0.34 & 0.37 & 0.29 \\
\hline 8.79 & 1R- $\alpha$-Pinene & 5.56 & - & - & - & 2.62 & 2.60 & 2.85 & - & - & - \\
\hline 9.16 & (+)-4-Carene & - & - & 0.58 & 7.31 & - & 0.30 & 3.51 & 0.30 & 3.55 & 3.96 \\
\hline 9.56 & p-Cymene & 1.10 & 4.82 & 2.73 & 3.80 & 3.07 & 1.94 & 2.45 & 3.81 & 4.45 & 3.34 \\
\hline 9.73 & D-Limonene & 15.52 & 5.72 & 3.37 & 1.10 & 10.58 & 9.34 & 8.80 & 4.56 & 3.60 & 2.30 \\
\hline 9.88 & Eucalyptol & 3.21 & 82.25 & 35.27 & 4.98 & 44.58 & 19.63 & 4.16 & 59.45 & 46.31 & 20.56 \\
\hline 10.47 & Z-Ocimene & 0.05 & - & - & - & - & - & - & - & - & - \\
\hline 11.02 & $\gamma$-Terpinene & - & 1.71 & 0.99 & 17.74 & 0.92 & 0.54 & 8.50 & 1.36 & 9.50 & 9.38 \\
\hline 12.47 & Terpinolene & 0.11 & - & - & 2.78 & - & - & 1.39 & - & 1.37 & 1.39 \\
\hline 13.28 & Linalool & 0.21 & - & 0.40 & - & 0.11 & 0.31 & 0.12 & 0.19 & - & 0.20 \\
\hline 13.78 & $\alpha$-Campholena & - & - & 0.11 & - & - & - & - & - & - & - \\
\hline 16.14 & (-)-Camphor & - & - & 10.43 & - & - & 5.36 & - & 5.10 & - & 5.32 \\
\hline 17.01 & Isoborneol & - & - & 1.52 & - & - & 0.77 & - & 0.71 & - & 0.75 \\
\hline 17.54 & Borneol & - & - & 2.71 & - & - & 1.38 & - & 1.32 & - & 1.39 \\
\hline 18.00 & (-)-Terpinen-4-ol & 0.28 & - & 0.45 & 43.94 & 0.17 & 0.38 & 20.85 & 0.26 & 20.94 & 22.02 \\
\hline 18.98 & $\alpha$-Terpineol & - & 0.16 & 2.31 & 3.61 & 0.11 & 1.24 & 1.75 & 1.22 & 1.81 & 3.03 \\
\hline 25.18 & $\alpha$-Bisabolol & - & - & - & 0.10 & - & - & - & - & - & - \\
\hline 26.98 & 4,4-Dimethylpent-2-enal & - & - & - & 0.11 & - & - & - & - & - & - \\
\hline 27.24 & $\delta$-Elemene & 1.00 & - & - & - & 0.44 & 0.45 & 0.51 & - & - & - \\
\hline 29.77 & $\alpha$-Copaene & 2.22 & - & - & 0.10 & 1.01 & 1.08 & 1.24 & - & - & - \\
\hline 30.57 & $\beta$-Cubebene & 0.18 & - & - & - & - & - & - & - & - & - \\
\hline 31.67 & $\alpha$-Gurjunene & - & - & - & 0.31 & - & - & - & - & - & - \\
\hline 32.48 & Caryophyllene & 24.56 & - & 4.92 & 0.39 & 11.50 & 14.62 & 13.10 & 2.36 & - & 2.73 \\
\hline 33.64 & (+)-Aromadendrene & - & - & - & 1.00 & - & - & 0.44 & - & 0.41 & 0.44 \\
\hline 34.69 & $\alpha$-Caryophyllene & 1.35 & - & - & - & 0.60 & 0.69 & 0.73 & - & - & - \\
\hline 34.96 & Aromadendrene & - & - & - & 0.38 & - & - & 0.12 & - & 0.15 & 0.15 \\
\hline
\end{tabular}


Table 1. Cont.

\begin{tabular}{|c|c|c|c|c|c|c|c|c|c|c|c|}
\hline \multirow{2}{*}{$\begin{array}{l}\mathrm{RT}^{\mathrm{a}} \\
(\mathrm{min})\end{array}$} & \multirow{2}{*}{ Composition } & \multicolumn{10}{|c|}{ Percentage $(\%)$ of Essential Oil Composition ${ }^{b}$} \\
\hline & & B & $\mathrm{E}$ & $\mathbf{R}$ & $\mathrm{T}$ & $\mathrm{BE}$ & BR & BT & ER & ET & TR \\
\hline 35.75 & Isoledene & - & - & - & 0.21 & - & - & - & - & - & - \\
\hline 36.76 & Pimarinal & - & - & - & - & - & - & 0.11 & - & - & - \\
\hline 36.89 & Viridiflorene & - & - & - & 0.80 & - & - & 0.36 & - & 0.34 & 0.33 \\
\hline 37.18 & $\gamma$-Elemene & - & - & - & 0.22 & - & - & - & - & - & - \\
\hline 37.43 & $\alpha$-Amorphene & 0.24 & - & - & - & - & - & - & - & - & - \\
\hline 37.98 & $\beta$-Bisabolene & 0.44 & - & - & - & 0.17 & - & - & - & - & - \\
\hline 38.59 & $\delta$-Cadinene & 0.60 & - & - & 0.87 & 0.24 & 0.26 & 0.75 & - & 0.38 & 0.39 \\
\hline 42.33 & Caryophyllene oxide & 2.62 & - & - & - & 1.17 & 1.24 & 1.37 & - & - & - \\
\hline 42.58 & Globulol & - & - & - & 0.33 & - & - & 0.14 & - & 0.11 & 0.11 \\
\hline 43.06 & Ledol & - & - & - & 0.14 & - & - & - & - & - & - \\
\hline 45.01 & $\alpha$-Cedrene & - & - & - & 0.16 & - & - & - & - & - & - \\
\hline 45.12 & Spathulenol & 0.17 & - & - & - & - & - & - & - & - & - \\
\hline
\end{tabular}

${ }^{a}$ Relative retention time (min); ${ }^{b}$ Letters refer to essential oils, for the essential oils: black pepper (B), eucalyptus (E), rosemary (R), and tea tree $(\mathrm{T})$. For the essential oil combinations: black pepper + eucalyptus (BE), black pepper + rosemary (BR), black pepper + tea tree (BT), eucalyptus + rosemary (ER), eucalyptus + tea tree (ET) and tea tree + rosemary (TR). (-) referred to none detected.

\subsection{Contact Toxicity of Pure Essential Oils}

When essential oils were evaluated for their insecticidal activities using the contact bioassay method (Table 2), all black pepper, eucalyptus, rosemary and tea tree essential oils showed the mortality against M. persicae. The result indicated that black pepper oil exerted contact toxicity against GPA in a time and dose-dependent manner, and the dose $5 \%$ resulted in the highest mortality of aphids, followed by the dose $3 \%$ then $2 \%$ and $1 \%$, compared with the untreated aphids at exposures of 1, 3, 6, 8 and $24 \mathrm{~h}$. The highest mortality of $80 \%$ was observed for both black pepper and tea tree essential oil at $24 \mathrm{~h}$ exposure time; however, mortality at the concentrations of 1, 2 and 3 was low. Conversely, eucalyptus and rosemary were less effective on the target pest compared with black pepper and tea tree oils. The mortality with eucalyptus oil was 5, 8.33, 16.67, 33.33, and 53.33\% at the concentration of $5 \%$ at $1,3,6,8$, and 24 h exposure times, and mortality from the rosemary oil at the dose $5 \%$ was $8.33,8.33$ (for 1 and $3 \mathrm{~h}$ ), 23.33, 35, and 60\%, respectively, at the same exposure time and $R^{2}=0.801$ (Adjusted $R^{2}=0.795$ ).

Table 2. Mortality of aphids Myzus persicae after contact treatment with four pure essential oils.

\begin{tabular}{|c|c|c|c|c|c|c|}
\hline \multirow[t]{2}{*}{$\mathrm{EO}^{\mathrm{a}}$} & \multirow[t]{2}{*}{$\begin{array}{c}\text { Concentration } \\
(\mu \mathrm{L} / \mathrm{mL})\end{array}$} & \multicolumn{5}{|c|}{ Mortality $\pm \mathrm{SD}^{\mathrm{b}}(\%)$ at Different Time (h) of Treatment } \\
\hline & & 1 & 3 & 6 & 8 & 24 \\
\hline \multirow[t]{5}{*}{ B } & 0 & $0.0 \pm 0.0$ & $0.0 \pm 0.0$ & $0.0 \pm 0.0$ & $0.0 \pm 0.0$ & $0.0 \pm 0.0$ \\
\hline & 1 & $0.0 \pm 0.0$ & $1.6 \pm 2.8$ & $5.0 \pm 5.0$ & $16.6 \pm 4.0$ & $25.0 \pm 5.0$ \\
\hline & 2 & $0.0 \pm 0.0$ & $1.6 \pm 2.8$ & $6.6 \pm 2.8$ & $16.6 \pm 5.7$ & $26.6 \pm 2.8$ \\
\hline & 3 & $1.6 \pm 2.8$ & $10.0 \pm 5.0$ & $21.6 \pm 2.8$ & $41.6 \pm 2.8$ & $66.6 \pm 5.7$ \\
\hline & 5 & $8.3 \pm 2.8$ & $8.3 \pm 2.8$ & $20.0 \pm 5.0$ & $53.3 \pm 7.2$ & $80.0 \pm 5.0$ \\
\hline \multirow[t]{5}{*}{$\mathrm{E}$} & 0 & $0.0 \pm 0.0$ & $0.0 \pm 0.0$ & $0.0 \pm 0.0$ & $0.0 \pm 0.0$ & $0.0 \pm 0.0$ \\
\hline & 1 & $0.0 \pm 0.0$ & $1.6 \pm 2.8$ & $5.0 \pm 2.9$ & $13.3 \pm 2.8$ & $16.6 \pm 2.8$ \\
\hline & 2 & $0.0 \pm 0.0$ & $0.0 \pm 0.0$ & $6.6 \pm 2.8$ & $13.3 \pm 2.8$ & $18.3 \pm 2.8$ \\
\hline & 3 & $5.0 \pm 5.0$ & $10.0 \pm 5.0$ & $16.6 \pm 2.8$ & $33.3 \pm 2.8$ & $55.0 \pm 0.0$ \\
\hline & 5 & $5.0 \pm 0.0$ & $8.3 \pm 2.8$ & $16.6 \pm 7.6$ & $33.3 \pm 2.8$ & $53.3 \pm 2.8$ \\
\hline \multirow[t]{5}{*}{$\mathrm{R}$} & 0 & $0.0 \pm 0.0$ & $0.0 \pm 0.0$ & $0.0 \pm 0.0$ & $0.0 \pm 0.0$ & $0.0 \pm 0.0$ \\
\hline & 1 & $0.0 \pm 0.0$ & $0.0 \pm 0.0$ & $5.0 \pm 2.9$ & $11.6 \pm 2.8$ & $23.3 \pm 2.8$ \\
\hline & 2 & $0.0 \pm 0.0$ & $1.6 \pm 2.8$ & $6.6 \pm 2.8$ & $15.0 \pm 5.0$ & $23.3 \pm 5.7$ \\
\hline & 3 & $3.3 \pm 2.8$ & $8.3 \pm 2.8$ & $15.0 \pm 5.0$ & $31.6 \pm 2.8$ & $56.6 \pm 2.8$ \\
\hline & 5 & $8.3 \pm 2.8$ & $8.3 \pm 2.8$ & $23.3 \pm 2.8$ & $35.0 \pm 5.0$ & $60.0 \pm 5.0$ \\
\hline
\end{tabular}


Table 2. Cont.

\begin{tabular}{|c|c|c|c|c|c|c|}
\hline \multirow[t]{2}{*}{$\mathrm{EO}^{\mathrm{a}}$} & \multirow[t]{2}{*}{$\begin{array}{c}\text { Concentration } \\
(\mu \mathrm{L} / \mathrm{mL})\end{array}$} & \multicolumn{5}{|c|}{ Mortality \pm SD $^{b}(\%)$ at Different Time (h) of Treatment } \\
\hline & & 1 & 3 & 6 & 8 & 24 \\
\hline \multirow[t]{5}{*}{$\mathrm{T}$} & 0 & $0.0 \pm 0.0$ & $0.0 \pm 0.0$ & $0.0 \pm 0.0$ & $0.0 \pm 0.0$ & $0.0 \pm 0.0$ \\
\hline & 1 & $0.0 \pm 0.0$ & $0.0 \pm 0.0$ & $5.0 \pm 0.0$ & $6.6 \pm 2.8$ & $13.3 \pm 2.8$ \\
\hline & 2 & $0.0 \pm 0.0$ & $0.0 \pm 0.0$ & $5.0 \pm 0.0$ & $8.3 \pm 2.8$ & $16.6 \pm 7.6$ \\
\hline & 3 & $5.0 \pm 5.0$ & $8.3 \pm 2.8$ & $20.0 \pm 5.0$ & $45.0 \pm 5.0$ & $65.0 \pm 5.0$ \\
\hline & 5 & $8.3 \pm 2.6$ & $13.3 \pm 2.8$ & $16.6 \pm 2.8$ & $45.0 \pm 5.0$ & $80.0 \pm 5.0$ \\
\hline
\end{tabular}

${ }^{\mathrm{a}}$ Letters refer to essential oils (EOs): black pepper (B), eucalyptus (E), rosemary (R), and tea tree (T). ${ }^{\text {b Stan- }}$ dard deviation.

\subsection{Contact Toxicity of Essential oil Mixtures}

All the mixtures of essential oils tested were active toward aphids (Table 3). Some of the combinations of essential oils tested, such as BT, ET, and TR, caused more than $80 \%$ mortality in GPA at the maximum dose used after $24 \mathrm{~h}$, while doses of 1 and $2 \%$ in some other combinations of essential oils showed less mortality than all types of combinations of essential oils. The contact activities of the three combinations TR, BT, and ET of essential oils (EOs) showed the highest mortality in the range of 93 to $98 \%$ at the concentrations of 3 and $5 \%$ for $24 \mathrm{~h}$ exposure time and $\mathrm{R}^{2}=0.787$ (Adjusted $\mathrm{R}^{2}=0.78$ ). However, the contact activities of other combinations of EOs were not ideal, causing less than $50-70 \%$ mortality during the $24 \mathrm{~h}$ exposure. The results of contact toxicity against GPA showed no significant differences between the EOs after $24 \mathrm{~h}$ exposure time.

Table 3. Mortality of aphids M. persicae after contact treatment with mixtures of six essential oils.

\begin{tabular}{|c|c|c|c|c|c|}
\hline \multirow[t]{2}{*}{$\mathrm{EO}^{\mathrm{a}}$} & \multirow[t]{2}{*}{$\begin{array}{l}\text { Concentration } \\
(\mu \mathrm{L} / \mathrm{mL})\end{array}$} & \multicolumn{4}{|c|}{ Mortality \pm SD $^{\mathbf{b}}(\%)$ at Different Time (h) of Treatment } \\
\hline & & 1 & 3 & 8 & 24 \\
\hline \multirow[t]{5}{*}{$\mathrm{BE}$} & 0 & $0.0 \pm 0.0$ & $0.0 \pm 0.0$ & $0.0 \pm 0.0$ & $0.0 \pm 0.0$ \\
\hline & 1 & $1.6 \pm 2.8$ & $1.0 \pm 5.0$ & $26.6 \pm 7.2$ & $51.6 \pm 7.6$ \\
\hline & 2 & $5.0 \pm 5.0$ & $13.3 \pm 5.0$ & $3.0 \pm 5.7$ & $53.3 \pm 8.6$ \\
\hline & 3 & $1.0 \pm 0.0$ & $13.3 \pm 2.8$ & $38.3 \pm 2.8$ & $61.6 \pm 1.6$ \\
\hline & 5 & $11.6 \pm 1.6$ & $21.6 \pm 1.7$ & $4.0 \pm 0.0$ & $65.0 \pm 2.8$ \\
\hline \multirow[t]{5}{*}{$\mathrm{BR}$} & 0 & $0.0 \pm 0.0$ & $0.0 \pm 0.0$ & $0.0 \pm 0.0$ & $0.0 \pm 0.0$ \\
\hline & 1 & $1.6 \pm 2.8$ & $1.0 \pm 5.0$ & $16.6 \pm 2.8$ & $5.0 \pm 5.0$ \\
\hline & 2 & $5.0 \pm 2.8$ & $15.0 \pm 2.8$ & $45.0 \pm 2.8$ & $55.0 \pm 2.8$ \\
\hline & 3 & $6.6 \pm 2.8$ & $2.0 \pm 2.8$ & $45.0 \pm 6.6$ & $7.0 \pm 5.0$ \\
\hline & 5 & $11.6 \pm 1.6$ & $2.0 \pm 3.3$ & $45.0 \pm 4.4$ & $71.6 \pm 5.3$ \\
\hline \multirow[t]{5}{*}{ BT } & 0 & $0.0 \pm 0.0$ & $0.0 \pm 0.0$ & $0.0 \pm 0.0$ & $0.0 \pm 0.0$ \\
\hline & 1 & $13.3 \pm 2.8$ & $25.0 \pm 5.7$ & $46.6 \pm 2.8$ & $76.6 \pm 2.8$ \\
\hline & 2 & $11.6 \pm 0.0$ & $26.6 \pm 0.0$ & $43.3 \pm 0.0$ & $83.3 \pm 0.0$ \\
\hline & 3 & $16.6 \pm 2.8$ & $3.0 \pm 5.0$ & $5.0 \pm 2.8$ & $98.3 \pm 1.6$ \\
\hline & 5 & $16.6 \pm 1.6$ & $33.3 \pm 4.4$ & $65.0 \pm 5.0$ & $98.3 \pm 1.6$ \\
\hline \multirow[t]{5}{*}{ ER } & 0 & $0.0 \pm 0.0$ & $0.0 \pm 0.0$ & $0.0 \pm 0.0$ & $0.0 \pm 0.0$ \\
\hline & 1 & $0.0 \pm 0.0$ & $3.3 \pm 2.8$ & $11.6 \pm 2.8$ & $4.0 \pm 5.0$ \\
\hline & 2 & $3.3 \pm 2.8$ & $16.6 \pm 5.7$ & $46.6 \pm 2.8$ & $55.0 \pm 5.7$ \\
\hline & 3 & $5.0 \pm 0.0$ & $16.6 \pm 2.8$ & $51.6 \pm 1.6$ & $78.3 \pm 4.4$ \\
\hline & 5 & $6.6 \pm 1.9$ & $18.3 \pm 1.6$ & $53.3 \pm 4.4$ & $76.6 \pm 1.6$ \\
\hline \multirow[t]{5}{*}{ ET } & 0 & $0.0 \pm 0.0$ & $0.0 \pm 0.0$ & $0.0 \pm 0.0$ & $0.0 \pm 0.0$ \\
\hline & 1 & $8.3 \pm 2.8$ & $31.6 \pm 7.2$ & $41.6 \pm 11.5$ & $7.0 \pm 7.6$ \\
\hline & 2 & $11.6 \pm 2.8$ & $25.0 \pm 0.0$ & $7.0 \pm 8.6$ & $75.0 \pm 5.0$ \\
\hline & 3 & $15.0 \pm 2.8$ & $26.6 \pm 2.8$ & $78.3 \pm 2.8$ & $93.3 \pm 5.0$ \\
\hline & 5 & $18.3 \pm 1.6$ & $31.6 \pm 2.8$ & $78.3 \pm 3.4$ & $95.0 \pm 5.0$ \\
\hline
\end{tabular}


Table 3. Cont.

\begin{tabular}{|c|c|c|c|c|c|}
\hline \multirow[t]{2}{*}{$\mathrm{EO}^{\mathrm{a}}$} & \multirow[t]{2}{*}{$\begin{array}{c}\text { Concentration } \\
(\mu \mathrm{L} / \mathrm{mL})\end{array}$} & \multicolumn{4}{|c|}{ Mortality $\pm \mathrm{SD}^{\mathrm{b}}(\%)$ at Different Time (h) of Treatment } \\
\hline & & 1 & 3 & 8 & 24 \\
\hline \multirow[t]{5}{*}{$\mathrm{TR}$} & 0 & $0.0 \pm 0.0$ & $0.0 \pm 0.0$ & $0.0 \pm 0.0$ & $0.0 \pm 0.0$ \\
\hline & 1 & $1.6 \pm 2.8$ & $8.3 \pm 5.7$ & $13.3 \pm 10.4$ & $35.0 \pm 8.6$ \\
\hline & 2 & $15.0 \pm 5.0$ & $28.3 \pm 2.8$ & $71.6 \pm 2.8$ & $86.6 \pm 2.8$ \\
\hline & 3 & $15.0 \pm 5.7$ & $33.3 \pm 4.4$ & $8.0 \pm 3.3$ & $96.6 \pm 1.6$ \\
\hline & 5 & $18.3 \pm 1.6$ & $35.0 \pm 2.8$ & $81.6 \pm 2.8$ & $98.3 \pm 1.6$ \\
\hline
\end{tabular}

a For the essential oil (EO) combinations: black pepper + eucalyptus (BE), black pepper + rosemary (BR), black pepper + tea tree (BT), eucalyptus + rosemary (ER), eucalyptus + tea tree (ET) and tea tree + rosemary (TR). ${ }^{\mathrm{b}}$ Standard deviation.

\subsection{Synergistic Activity among Essential Oil Mixtures}

Insecticidal activity among four types of essential oils (black pepper, eucalyptus, rosemary and tea tree) were investigated (Table 4). The following EO combinations showed several synergistic interactions; the most significant synergy based on Wadley's determination was the combination of BT, ET, and TR. the binary combination of two essential oils produced lower $\mathrm{LC}_{50}$ than the individual oil. The synergy interaction was found with the mixture of black pepper and tea tree, eucalyptus and tea tree, as well as tea tree and rosemary based on Wadley's calculation, and the synergy ratio was $R>1.5$. However, the combination of black pepper and eucalyptus, black pepper and rosemary, and eucalyptus and rosemary showed additive interaction because the synergy ratio was $R<1.5$. No one of the essential oil mixtures showed antagonistic interaction $R<0.5$ based on Wadley's calculation.

Table 4. Synergistic interaction of six binary combinations of four essential oils against aphids M. persicae after $24 \mathrm{~h}$ contact application.

\begin{tabular}{|c|c|c|c|c|c|c|c|c|c|c|}
\hline \multirow{2}{*}{ EO } & \multirow{2}{*}{$\mathrm{LC}_{50}(95 \% \mathrm{CI})^{\mathrm{a}}$} & \multirow{2}{*}{ Intercept } & \multirow{2}{*}{ Slope } & \multirow{2}{*}{$d f^{b}$} & \multirow{2}{*}{$X^{2 c}$} & \multirow{2}{*}{$\mathbf{H}^{\mathrm{d}}$} & \multicolumn{4}{|c|}{ Expected $\mathrm{LC}_{50} \mathrm{e}$} \\
\hline & & & & & & & $H \& P^{f}$ & Wadley ${ }^{g}$ & $\mathbf{R}^{\mathbf{h}}$ & $S^{i}$ \\
\hline B & $5.16(4.57-5.75)$ & 2.00 & -0.39 & 58 & 1.41 & 0.02 & & & & \\
\hline $\mathrm{E}$ & $8.27(6.39-10.14)$ & 1.94 & -0.23 & 58 & 4.42 & 0.07 & & & & \\
\hline $\mathrm{T}$ & $5.03(4.56-5.50)$ & 2.39 & -0.47 & 58 & 7.64 & 0.13 & & & & \\
\hline $\mathrm{R}$ & 7.76 (6.05-9.47) & 1.81 & -0.23 & 58 & 2.12 & 0.03 & & & & \\
\hline $\mathrm{BE}$ & $11.86(3.20-20.53)$ & 1.02 & -0.09 & 58 & 0.17 & 0.00 & 5.43 & 6.35 & 0.54 & Add \\
\hline BT & $1.57(1.28-1.88)$ & 0.79 & -0.50 & 58 & 0.65 & 0.01 & 3.81 & 5.09 & 3.24 & Syn \\
\hline $\mathrm{BR}$ & 7.45 (4.85-10.05) & 1.09 & -0.15 & 58 & 3.95 & 0.06 & 5.17 & 6.2 & 0.83 & Add \\
\hline ET & $2.36(2.00-2.71)$ & 0.86 & -0.36 & 58 & 1.97 & 0.03 & 4.58 & 6.26 & 2.65 & Syn \\
\hline ER & $5.4(4.41-6.39)$ & 1.30 & -0.24 & 58 & 10.41 & 0.17 & 5.95 & 8.01 & 1.48 & Add \\
\hline $\mathrm{TR}$ & $2.23(2.04-2.42)$ & 1.86 & -0.83 & 58 & 29.39 & 0.50 & 5.14 & 6.1 & 2.74 & Syn \\
\hline
\end{tabular}

${ }^{a}$ Lethal concentration $\left(\mathrm{LC}_{50}\right) \pm$ Confidence Interval $(\mathrm{CI}) ;{ }^{\mathrm{b}} \mathrm{df}=$ Degree of freedom; ${ }^{\mathrm{c}} \mathrm{X}^{2}=$ Chi square; ${ }^{\mathrm{d}} \mathrm{H}=$ Heterogeneity factors; ${ }^{\mathrm{e}}$ Expected $\mathrm{LC}_{50}$ based on each calculation model; ${ }^{\mathrm{f}} \mathrm{H \& P}=$ Hewlett and Plackett's calculation of expected $\mathrm{LC}_{50} ;{ }^{\mathrm{g}}$ Wadley's calculation of expected $\mathrm{LC}_{50} ;{ }^{\mathrm{h}} R=$ Determination of interaction of the mixture based on Wadley's determination method: when $R>1.5$, synergistic (Syn) interaction; when $1.5 \geq R>0.5$, additive (Add) interaction; when $R \leq 0.5$, antagonistic (Anta) interaction; ${ }^{i} \mathrm{~S}=$ Synergy ratio from Wadley's calculation.

\subsection{Storage and Temperature Stability of Combined Essential Oils}

The essential oil mixtures were stored at three different temperatures $(15,25$, and $35^{\circ} \mathrm{C}$ ) for one, two, and three months, and all mixtures were introduced to FTIR analysis to determine functional group changes during the storage period. The functional groups present in the mixtures of essential oils were determined by comparing the vibration frequencies in the wave number. Figures 1-6 present the spectral absorption of essential oil mixtures obtained from BE, BR, BT, ER, ET, and RT measured in the wave number range $4000-400 \mathrm{~cm}^{-1}$. The FTIR spectrum of BE showed strong broadband at $2922 \mathrm{~cm}^{-1}$ and was assigned to the Alkanes $\mathrm{C}-\mathrm{H}$ stretch, a medium band intensity vibration at $1644 \mathrm{~cm}^{-1}$ was 
assigned to $\mathrm{NH}_{2}$, the strong methylene/methyl band at 1464.95 and $1446.16 \mathrm{~cm}^{-1}$. The peaks of IR at 2931 and $2842 \mathrm{~cm}^{-1}$ were due to Alkyl C-H asymmetric and symmetric stretching. The strong bands at $1631 \mathrm{~cm}^{-1}$ and $1633 \mathrm{~cm}^{-1}$ were indicative of aromatic compound C-H bending, at 1306-1361 $\mathrm{cm}^{-1}$ represented phenol compound -O-H and C-H stretch bands, while the number wave at $1015-1270 \mathrm{~cm}^{-1}$ showed the strong band of $\mathrm{C}-\mathrm{O}$. The position of the Alkenyl $\mathrm{C}=\mathrm{C}$ stretching regularity varied slightly as a function of location around the double bond. Carbonyl compounds were often the strongest bands in the spectrum and were located between 1825 and $1575 \mathrm{~cm}^{-1}$. For a double bond, the function group played an important role in the observation of the carbonyl group. This included a connection of an aromatic group to a $\mathrm{C}=\mathrm{C}$ or $\mathrm{C}=\mathrm{O}$. The wave number at $985 \mathrm{~cm}^{-1}$ indicated a strong or medium band for alkene compound $\mathrm{C}=\mathrm{C}-\mathrm{H}$ and at $920.1 \mathrm{~cm}^{-1}$ represented group C-H. For other oils no change in stretching and bending vibrations for $\mathrm{C}-\mathrm{H}, \mathrm{C}-\mathrm{O}, \mathrm{C}=\mathrm{C}$ and $\mathrm{O}-\mathrm{H}$ bonds were observed with respect to temperature and storage time.

(a)
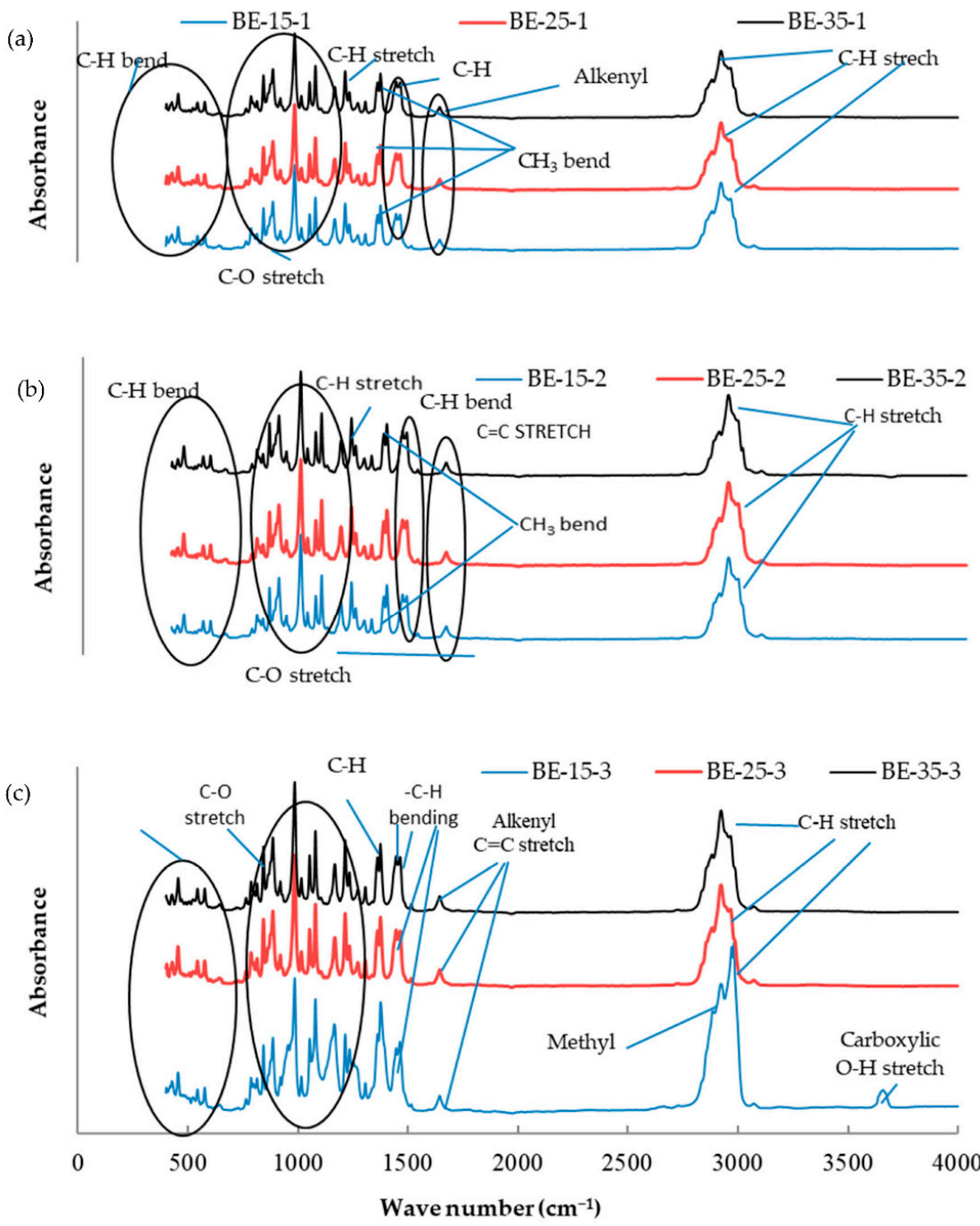

Figure 1. Fourier-transform infrared spectroscopy (FTIR) analysis for the essential oil combination of black pepper + eucalyptus (BE) at different temperatures $\left(15,25\right.$, and $\left.35^{\circ} \mathrm{C}\right)$ and different times of storage (1-3 months) (different colors refer to different temperature per subfigure). (a) This figure refer to the effect of different temperature at 15,25 , and $35^{\circ} \mathrm{C}$ on the combination of $\mathrm{BE}$ stored for one month; (b) the second subfigure refer to different temperature at 15,25 , and $35^{\circ} \mathrm{C}$ on the combination of $\mathrm{BE}$ stored for two months; (c) the third subfigure refer to different temperature at 15,25 , and $35^{\circ} \mathrm{C}$ on the combination of BE stored for three months. 

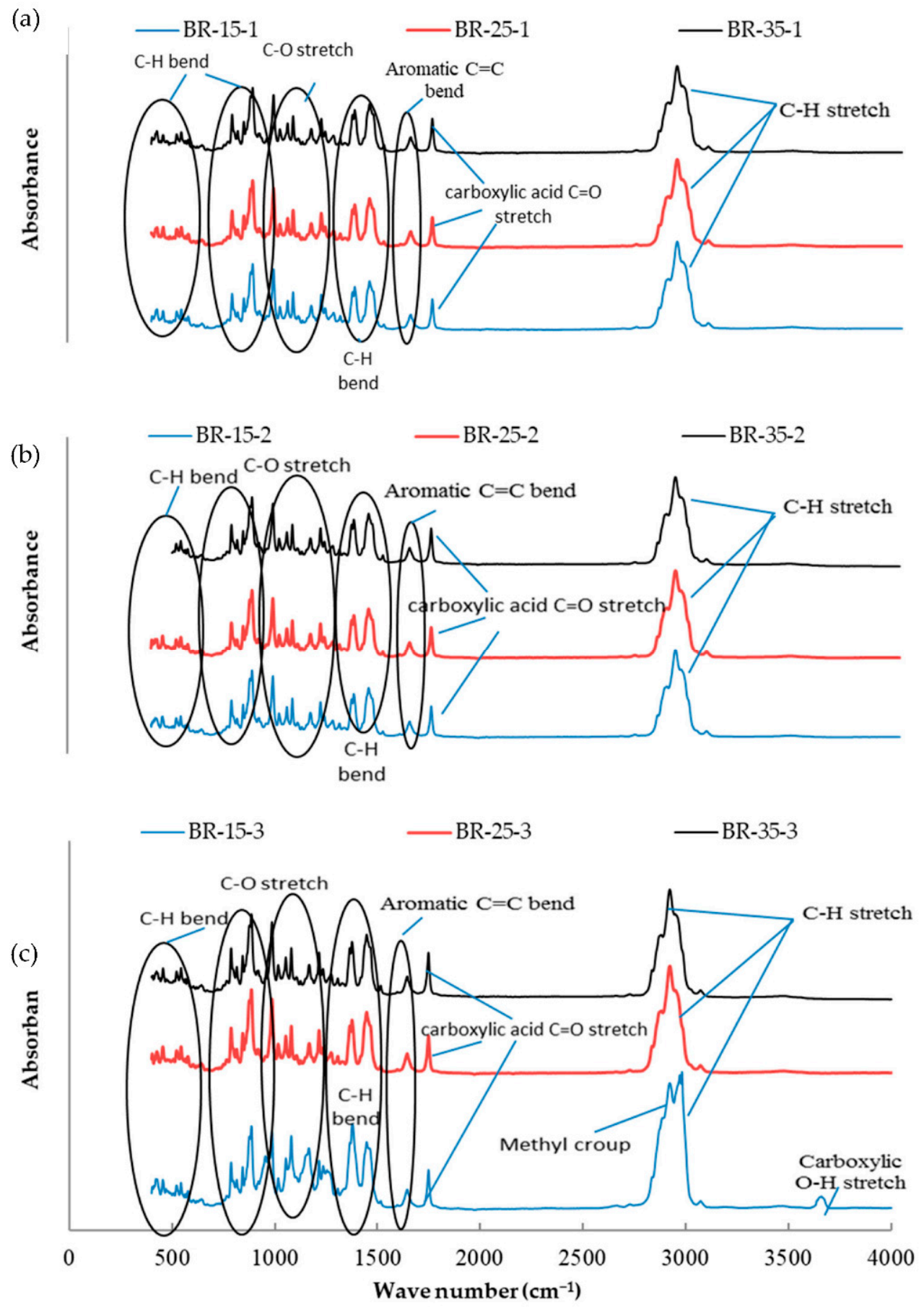

Figure 2. Fourier-transform infrared spectroscopy (FTIR) analysis for the essential oil combination of black pepper + rosemary (BR) at different temperatures $\left(15,25\right.$, and $\left.35^{\circ} \mathrm{C}\right)$ and different times of storage (1-3 months) (different colors refer to different temperature per subfigure). (a) This figure refer to the effect of different temperature at 15,25 , and $35^{\circ} \mathrm{C}$ on the combination of BR stored for one month; (b) the second subfigure refer to different temperature at 15,25 , and $35^{\circ} \mathrm{C}$ on the combination of BR stored for two months; (c) the third subfigure refer to different temperature at 15,25 , and $35^{\circ} \mathrm{C}$ on the combination of BR stored for three months. 
(a)
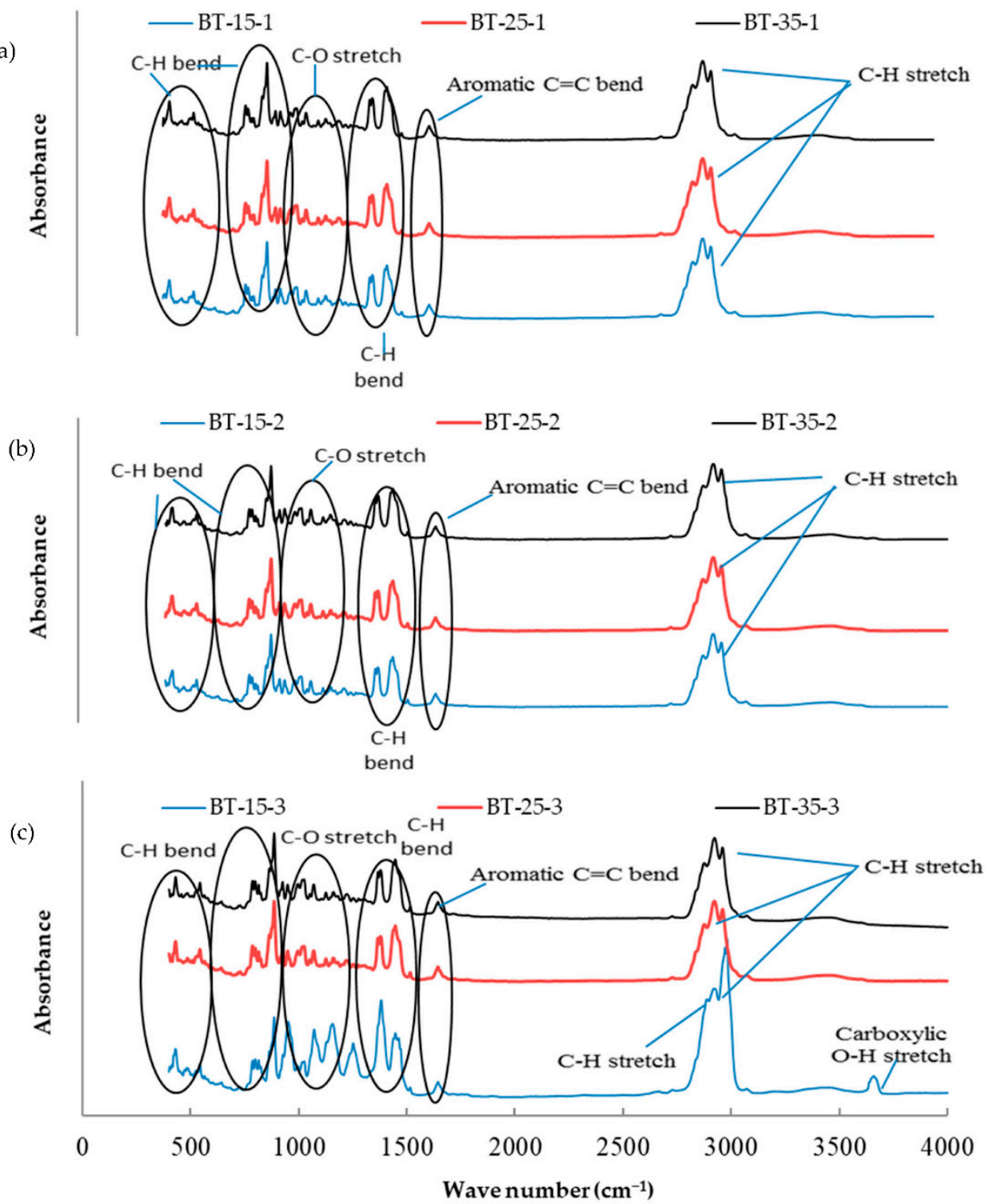

Figure 3. Fourier-transform infrared spectroscopy (FTIR) analysis for the essential oil combination of black pepper + tea tree (BT) at different temperatures $\left(15,25\right.$, and $\left.35^{\circ} \mathrm{C}\right)$ and different times of storage (1-3 months) (different colors refer to different temperature per subfigure). (a) This figure refer to the effect of different temperature at 15,25 , and $35^{\circ} \mathrm{C}$ on the combination of BT stored for one month; (b) the second subfigure refer to different temperature at 15,25 , and $35^{\circ} \mathrm{C}$ on the combination of BT stored for two months; (c) the third subfigure refer to different temperature at 15,25 , and $35{ }^{\circ} \mathrm{C}$ on the combination of BT stored for three months. 

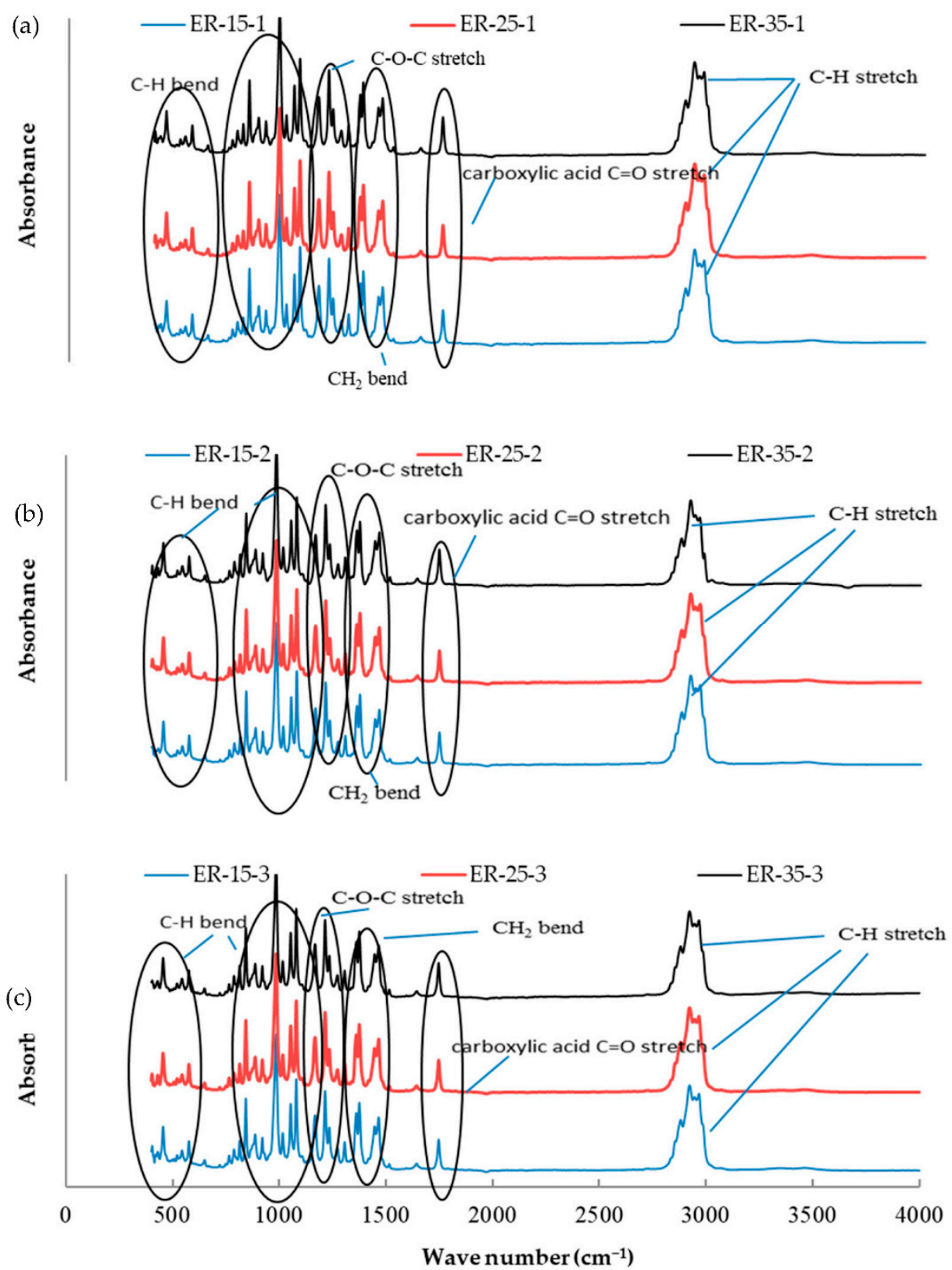

Figure 4. Fourier-transform infrared spectroscopy (FTIR) analysis for the essential oil combination of eucalyptus + rosemary (ER) at different temperatures $\left(15,25\right.$, and $\left.35^{\circ} \mathrm{C}\right)$ and different times of storage (1-3 months) (different colors refer to different temperature per subfigure). (a) This figure refer to the effect of different temperature at 15,25 , and $35^{\circ} \mathrm{C}$ on the combination of ER stored for one month; (b) the second subfigure refer to different temperature at 15,25 , and $35^{\circ} \mathrm{C}$ on the combination of ER stored for two months; (c) the third subfigure refer to different temperature at 15,25 , and $35{ }^{\circ} \mathrm{C}$ on the combination of ER stored for three months. 

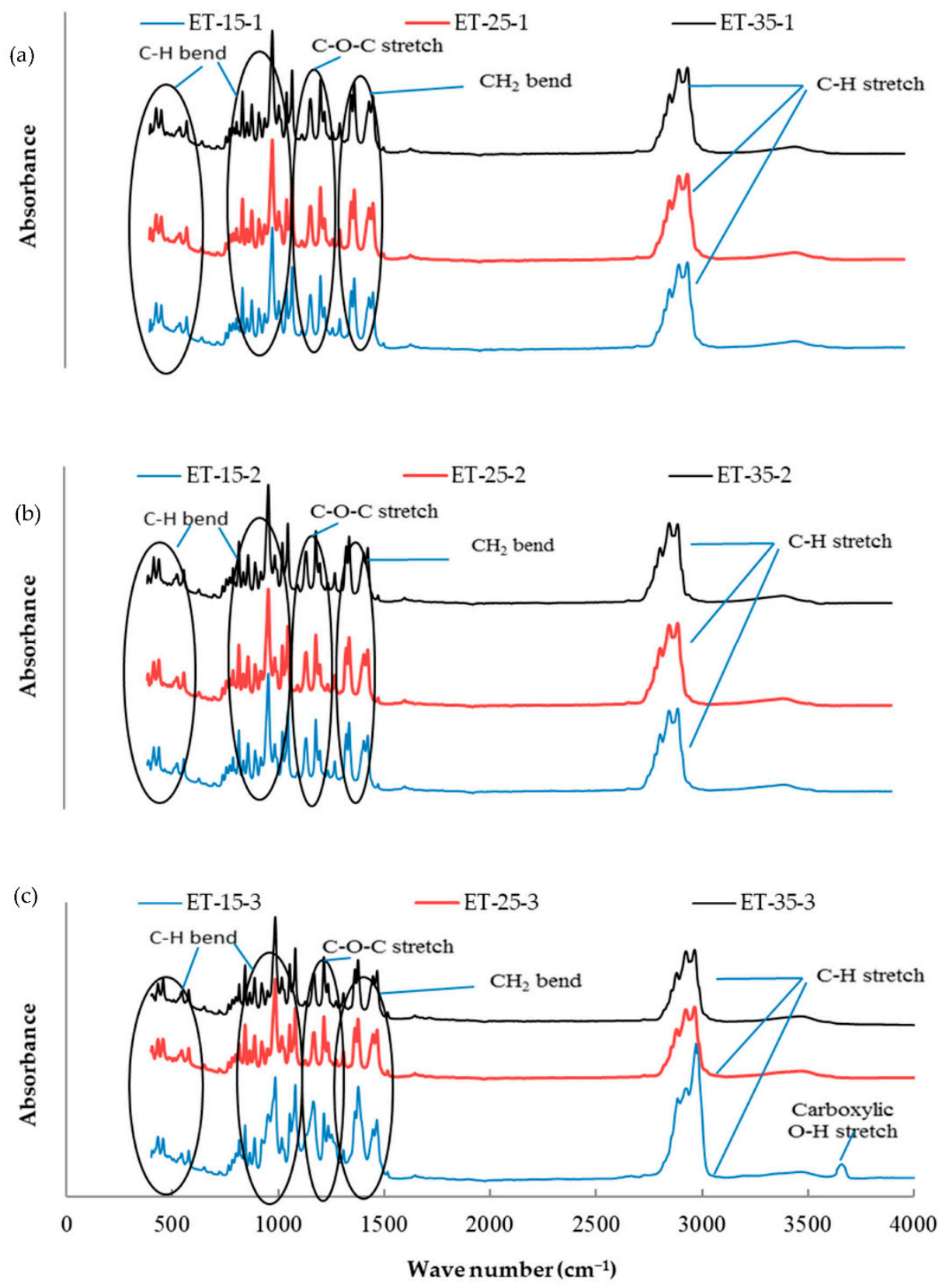

Figure 5. Fourier-transform infrared spectroscopy (FTIR) analysis for the essential oil combination of eucalyptus + tea tree (ET) at different temperatures $\left(15,25\right.$, and $\left.35^{\circ} \mathrm{C}\right)$ and different times of storage (1-3 months) (different colors refer to different temperature per subfigure). (a) This figure refer to the effect of different temperature at 15,25 , and $35^{\circ} \mathrm{C}$ on the combination of ET stored for one month; (b) the second subfigure refer to different temperature at 15,25 , and $35^{\circ} \mathrm{C}$ on the combination of ET stored for two months; (c) the third subfigure refer to different temperature at 15,25 , and $35{ }^{\circ} \mathrm{C}$ on the combination of ET stored for three months. 
(a)

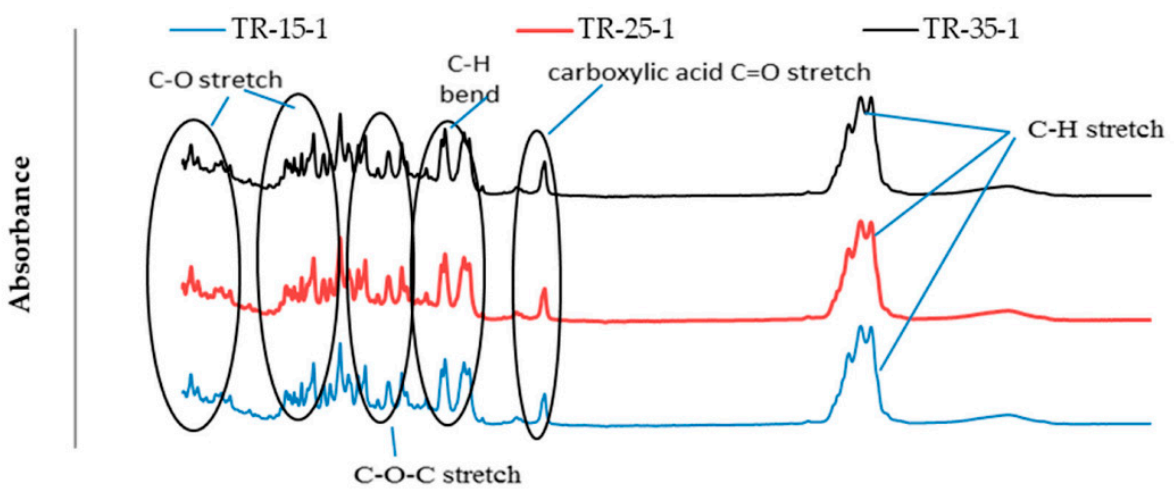

(b)

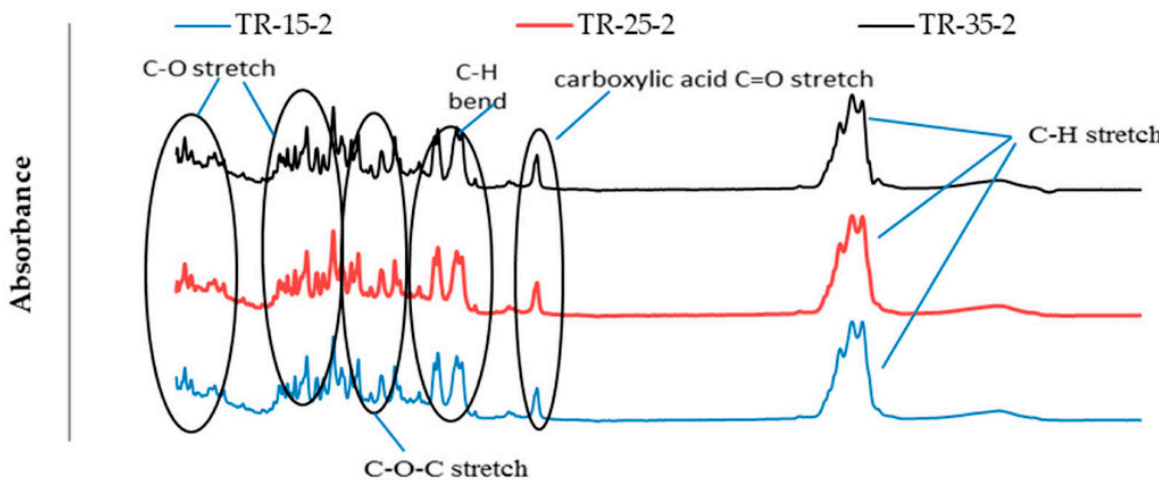

(c)

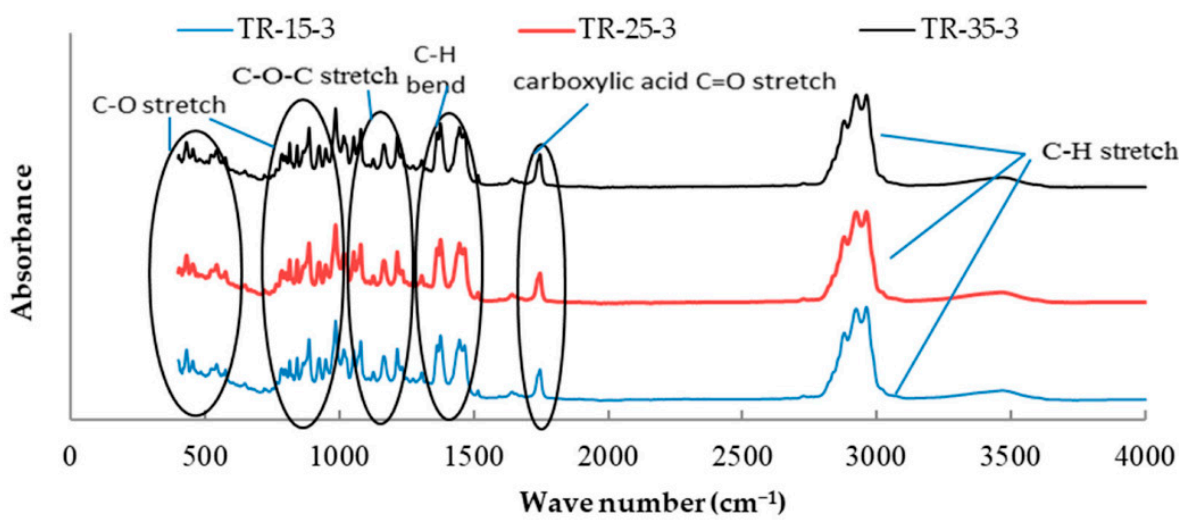

Figure 6. Fourier-transform infrared spectroscopy (FTIR) analysis for the essential oil combination of tea tree + rosemary (TR) at different temperatures $\left(15,25\right.$, and $\left.35^{\circ} \mathrm{C}\right)$ and different times of storage (1-3 months) (different colors refer to different temperature per subfigure). (a) This figure refer to the effect of different temperature at 15,25 , and $35^{\circ} \mathrm{C}$ on the combination of TR stored for one month; (b) the second subfigure refer to different temperature at 15,25 , and $35^{\circ} \mathrm{C}$ on the combination of TR stored for two months; (c) the third subfigure refer to different temperature at 15,25 , and $35{ }^{\circ} \mathrm{C}$ on the combination of TR stored for three months.

\section{Discussion}

Plant essential oils are potentially valuable for GPA control. They performed in many ways on several types of insects and can be applied to crops or stored products [24]. Black pepper, eucalyptus, rosemary, and tea tree are known to possess antifeedant, repellent, ovicidal and insecticidal activities against many insect species [16]. Additionally, essential oils can be highly effective on insecticide-resistant insects as well as the use of chemical pesticides can be caused pesticides residues in the treated plants when used against insect pests $[25,26]$. In this study, the influences of essential oils varied according to oil type (pure oil and mixture), time, and dose on $M$. persicae. The insecticidal activity against GPA was observed with 1, 2, 3, and 5\%. These essential oils might be important applicants for 
natural GPA control agents. All essential oils applied by contact proved toxic to M. persicae, although they differed in their efficacy. The two binary essential oil combinations resulted in higher mortality than the effect of a single essential oil. Synergistic combinations led to enhanced toxicity of the essential oil mixture and appeared to have multiple modes of action in pests compared with the use of a single essential oil, as shown in Tak et al. [26].

The GC-MS analysis (Table 1) showed that differences in chemical composition and its percentages were tested between essential oils in the pure and mixed oils. Black pepper GCMS analysis showed that Caryophyllene was the most abundant major constituent followed by $\mathrm{D}$-Limonene, $\alpha$-Pinene, $\beta$-Pinene, and Sabinene. All these constituents affected various pests, and these results were consistent with [12,27]. The results indicated that Eucalyptol was one of the major chemical compositions in the eucalyptus essential oil, which made up $(82.25 \%)$ of the total chemical composition of the oil. Eucalyptol has insecticidal activities against many insects, as shown in many previous studies [2,18]. In addition, the main constituents in rosemary essential oil were Eucalyptol, $\alpha$-Pinene, $(-)$-Camphor, and $\beta$ Pinene. These components exhibit pesticide action that is used in pest control, as presented in many past experiments $[6,7,14,27]$. Moreover, the result showed that tea tree essential oil contained the highest compounds, which are (-)-Terpinen-4-ol and $\gamma$-Terpinene. These two major constituents have insecticidal properties and affect insect enzymes such as AChE, GST, and CarE [23,28,29]. However, the proportions of the main compounds in all types of tested essential oils changed after binary mixing. Chemical compositions in the BE combination were Caryophyllene, D-Limonene, $\alpha$-Pinene, $\beta$-Pinene, and Sabinene. The result of GC-MS indicated variations of chemical compound percentages between the two pure essential oils as compared to their mixtures. In the BE mixture, the main constitutions were reduced to nearly half, compared with black pepper and eucalyptus separately (Table 1). The BE combination also showed most of the compounds found in the mixture that were not found in the pure oils, and this might have enhanced the range of insecticidal activity between oil constituents. Whereas in the BR combination, the highest compound amounts were $\alpha$-Pinene, $\beta$-Pinene, D-Limonene, Eucalyptol, and Caryophyllene; these amounts were decreased compared with their purity before mixing. In BT, the result indicated that (-)-Terpinen-4-ol and Caryophyllene were the highest constituents in the mixture, this finding was consistent with [29], which indicated the high amounts of Terpinen-4-ol and Caryophyllene in tea tree M. alternifolia oil. In our study tea tree oil and binary mixtures that included tea tree oil (BT, ET, and TR) showed maximum efficacy against GPA, and this can be attributed to Terpinen-4-ol as the major constituent in all the above four oils. Moreover, ER, ET, and TR had the same components: $\alpha$-Pinene $(8.28,1.59$, and $9.28 \%$, respectively), Eucalyptol $(59.45,46.31$, and $20.56 \%$, respectively), $\gamma$-Terpinene (1.36, 9.50, and 9.38, respectively) and (-)-Camphor (5.10, 0, and 5.32\%). All these compounds have properties against various types of insects, as shown in previous studies $[17,30]$.

The results of this study showed the insecticidal effects of black pepper, eucalyptus, rosemary, and tea tree essential oils and their binary combinations (BE, BR, BT, ER, ET, and TR) in various concentrations on the GPA. However, there were differences in the bio-insecticidal effects of 10 essential oils (four pure and six binary combination oils), despite them all having significant aphicidal activity on $M$. persicae in various mortality percentages based on the concentrations of essential oils, especially with high test doses for $24 \mathrm{~h}$ exposure time. The efficacy of essential oils depends upon their chemical composition and the proportion of each constituent present in the mixture. The essential oil constituents vary from one type to another, depending on plant species [7]. Hollingsworth et al. [31] and Liška et al. [32] reported that $\alpha$-Pinene, D-Limonene, and Camphene, which were major constituents, demonstrated aphicidal properties against the wooly beech aphid Phyllaphis fagi and the palm aphid Cerataphis brasiliensis. Conversely, previous studies showed that limonene is able to attract aphids' natural enemies, so essential oil containing a high amount of D-Limonene can act as an attractant for parasitoids and predators [30], while the compounds Eugenol and 1,8-Cineole have been reported effective against many 
insects, including aphids [31-33]. Other major constituents, such as Terpinene-4-ol, Terpinene, 4-Carene, and $\alpha$-Phellandrene also have an insecticidal effect against several insects, and these compounds were found in the tested essential oils (black pepper, eucalyptus, rosemary, and tea tree) [34,35]. Some previous work related to the aphicidal effects of rosemary oil were consistent with our findings. Rosemary oil has insecticidal effects against several insects and is used in many commercial products as an insecticide [25]. A study conducted by Digilio et al. [36] found that rosemary is a repellent and contact toxin against M. persicae and has a greater ability to penetrate through the cuticle of aphids than to be absorbed from the gut and intestines. These findings are similar to the results presented by Tomova et al. [37], indicating an increase in the mortality percentage of aphids when exposed to diverse essential oils; Görür et al. [38] confirmed the significant effects of the essential oil volatiles against three species of aphids, demonstrating a potential for aphid control. Black pepper and tea tree essential oil contact application resulted in $80 \%$ mortality in the GPA; there is a report of comparable findings with results of nearly $100 \%$ mortality caused by black pepper and tea tree essential oils against the rose-grain aphid [22]. In addition, our findings indicated that the mortality rates caused by eucalyptus and rosemary oils were 94.44 and $95.56 \%$, respectively (Tables 2 and 3). However, the combination of TR, ET, and BT essential oils can cause 98.33, 95.00, and 98.33\% mortality, respectively, while contact application showed that the parallel effect of essential oils against cabbage aphids resulted in more than $85 \%$ mortality [39]. Conversely, it was concluded that there was an impact on the aphid population on the plant when exposed to a low dose [39]. Our findings on the insecticidal effects of the tested combined essential oils showed high mortality rates caused by TR, ET, and BT, and more than $96 \%$ mortality for BR, BT, and ET. In the series of concentrations applied, mortality was concentration-dependent. The reason for these results was the essential oils' constituents and their volatiles. Our result was consistent with [37], who showed high mortality rates in M. persicae and Acyrthosiphon pisum by using different doses of various essential oils (Tables 2 and 3). Regarding the use of these oils, it can be concluded that black pepper and tea tree have stronger insecticidal potential than eucalyptus and rosemary.

We observed that individual oils varied in their toxicity to the aphids and some oil types were more toxic to aphids, especially in a high dose. The mixed binary essential oils were also shown to be additive, synergistic, and no combinations were antagonistic. We found their toxicity was as high as expected, especially with a short time and a low dose. The toxicity of the binary mixtures of oils increased the mortality of aphids. This indicated that some combinations had a synergistic effect; however, synergistic activities were observed in the $\mathrm{BT}, \mathrm{ET}$, and TR combinations, $\mathrm{LC}_{50}$ values were $1.57,2.36$, and 2.23 , respectively, compared with individual $\mathrm{LC}_{50}$ values of $5.16,8.27,5.03$, and 7.76 for $\mathrm{B}, \mathrm{E}, \mathrm{T}$, and $\mathrm{R}$, respectively (Table 4). In most mixtures, additive interaction was observed between two mixed oils such as BE, BR, and ER, and that happened because the binary combination may have returned to the interaction between the essential oils' components [40]. Synergistic interaction in the cases of BT, ET, and TR against M. persicae can be attributed to: (1) the difference in the insecticidal mechanisms of black pepper and tea tree from other essential oils on M. persicae; and (2) the synergistic effect being due to the essential oils' compounds interaction. These findings were parallel to Pavela [41], who reported that synergistic insecticidal activities could be observed not only in the combination of essential oils but also in their constituents, as well as between synthetic insecticides with essential oils.

The findings of our study indicated that the three tested temperatures had no effect on essential oil stability based on FTIR analysis, as no changes in functional groups could be seen in all periods of storage. Our results were consistent with Turek and Stintzing [24], who demonstrated oil stability at various temperatures $\left(5-38{ }^{\circ} \mathrm{C}\right)$, and that it showed no effect from temperature for three months when stored. All these peaks of function groups were not affected by the storage temperature tested on the essential oils or the time of storage, and all groups remained at the same wavenumber location. FTIR analysis was 
performed because is a fast and relatively cheap technique that might allow direct function group measurements of components in mixtures.

\section{Materials and Methods}

\subsection{Essential Oils and Chemicals}

Black pepper Piper nigrum, rosemary Rosmarinus officinalis, eucalyptus blue gum Eucalyptus globulus, and tea tree Melaleuca alternifolia $100 \%$ pure essential oils were obtained from Essential Pure Natural Select Ingredient supplies (Range Products Pty. Ltd., Perth, Western Australia), which were extracted by steam distillation (Table 5). Methanol 99.9\% and hexane 97\% were purchased from Sigma-Aldrich (Australia), and acetone 99.5\% and ethanol 99.0\% were purchased from Asia Pacific Specialty Chemicals Ltd., NSW, Australia.

Table 5. List of essential oils used in this study, including origin and plant part used.

\begin{tabular}{cccc}
\hline Essential Oil Name & Plant Family & Origin & Plant Tissues Used \\
\hline Black pepper & Piperaceae & India & Berries \\
Eucalyptus Blue Gum & Myrtaceae & Australia & Wood and Leaves \\
Rosemary & Lamiaceae & Spain & Herb \\
Tea tree & Myrtaceae & Australia & Leaves \\
\hline
\end{tabular}

\subsection{Aphid Rearing}

GPA Myzus persicae (Sulzer) were obtained from two locations, Agricultural Biotechnology Centre (SABC) at Murdoch University and the field (GPS Coordinates: $32.0699^{\circ} \mathrm{S}$, $\left.115.8426^{\circ} \mathrm{E}\right)$, Western Australia. Green peach aphids were reared in a glasshouse located at Murdoch University, Western Australia, on cabbage Brassica oleracea var. capitata and sweet capsicum Capsicum annuum potted plants under the glasshouse condition for aphid colonies: the temperature ranged between $18 \pm 2{ }^{\circ} \mathrm{C}$ and $25 \pm 2{ }^{\circ} \mathrm{C}$ during daylight and at night with humidity between $60 \pm 2 \%$ and $75 \pm 2 \%$, respectively, and a photoperiod L18:D6. The temperature and humidity were recorded using the HoBoware ${ }^{\circledR}$ (temperature/Relative Humidity data logger) and its data loggers software version 3.7.18 (Onset Company, One Temp Pty. Ltd., Adelaide, Australia), held inside the glasshouse. M. persicae were transferred by a fine brush and placed on the leaves of cabbage and capsicum plants.

\subsection{Determination of Essential Oil Compounds Using Gas Chromatography-Mass Spectrophotometry (GC-MS)}

GC-MS analysis was carried out for $100 \%$ pure essential oil of black pepper, eucalyptus blue gum, rosemary, and tea tree, and their binary combinations by using a Shimadzu GC-MS model QP2010 series, installed with an SGE main category BPX5 column, using $30 \mathrm{~m} \times 0.25 \mathrm{~mm}$ film thickness $0.25 \mu \mathrm{m}$ (Kinesis Australia Pty Ltd., Qld, Australia) and AOC-5000 autosampler (Shimadzu, Kyoto, Japan) as an autosampler. The parameter of GC-MS analysis used the following method: injector temperature $220^{\circ} \mathrm{C}$; pressure $63.43 \mathrm{kPa}$; column flow $1.07 \mathrm{~mL} / \mathrm{min}$; linear velocity $37.8 \mathrm{~cm} / \mathrm{s}$; sample injected volume $1 \mu \mathrm{L}$ diluted with hexane. Gas chromatography coupled to a mass selective detector (MSD) were recorded with ionization and interface temperature of $200^{\circ} \mathrm{C}$; the solvent cut time was $1.5 \mathrm{~min}$ and the carrier gas helium. Two replicates for each essential oil were injected. The individual constituent of each essential oil was identified and achieved by comparing the obtained mass spectra for each component with the values stored in mass spectra libraries and the NIST database with data previously reported in the literature. The percentage composition of the oils was calculated in peak areas using the normalization method.

\subsection{Contact Toxicity Bioassay of Pure and Combination Essential Oils}

Four concentrations were used to test the contact toxicity for 10 essential oils, which were four pure essential oils of black pepper, eucalyptus blue gum, rosemary, and tea tree and six binary mixtures of essential oils of black pepper + eucalyptus, black pepper + rosemary, black pepper + tea tree, eucalyptus + rosemary, eucalyptus + tea tree, and rosemary + tea 
tree (BE, BR, BT, ER, ET, and TR). Three replications were used per treatment of essential oil for the pure and mixture. The control treatment was treated as above but using the solvent only. Between 20 and 30 aphids (different stages of aphids) were placed on filter paper in a $9 \mathrm{~cm}$ Petri dish. Each treatment was sprayed by using a micro-spray size $5 \mathrm{~mL}$ sprayer, and $1 \mathrm{~mL}$ of essential oil was applied according to each concentration. Petri dishes were covered with mesh and placed in an incubator chamber $\left(25 \pm 2{ }^{\circ} \mathrm{C}, 16: 8, \mathrm{~L}: \mathrm{D}, 65 \pm 5 \% \mathrm{RH}\right)$. Mortality was determined under a microscope after $1,3,6,8$, and $24 \mathrm{~h}$. Three replicates were used for each concentration.

\subsection{Synergistic Interactions between Essential Oils}

To evaluate potential synergies between the essential oils (black pepper, eucalyptus blue gum, rosemary, and tea tree), mixtures were prepared maintaining the same concentration of single essential oil, following 1:1 ratio of the oils. Mixtures were applied to aphid adults and their $\mathrm{LC}_{50}$ values were estimated after $24 \mathrm{~h}$. The relationships of the mixtures were determined by using two statistical models, which were Hewlett and Plackett's model and Wadley's model, to compare expected and observed LC $_{50}$ values as shown in Equations as per Tak et al. [26]. Depending on Hewlett and Plackett's calculation, the expected $\mathrm{LC}_{50}$ values (assuming additive interaction) were determined from:

$$
\mathrm{E}=\left(\mathrm{a} \times \mathrm{LC}_{50}(\mathrm{a})\right)+\left(\mathrm{b} \times \mathrm{LC}_{50}(\mathrm{~b})\right)+\left(\mathrm{c} \times \mathrm{LC}_{50}(\mathrm{c})\right)+\cdots+\left(\mathrm{n} \times \mathrm{LC}_{50}(\mathrm{n})\right)
$$

where E refers to expected $\mathrm{LC}_{50}$ and $\mathrm{a}$ is the proportion of oil $\mathrm{A}$ in the mixture. $\mathrm{LC}_{50}(\mathrm{a})$ is the $\mathrm{LC}_{50}$ of oil $\mathrm{A}$ and $\mathrm{b}$ is the proportion of oil $\mathrm{B}$ in the mixture, as well as $\mathrm{LC}_{50}(\mathrm{~b})$ is the $\mathrm{LC}_{50}$ of oil $\mathrm{B}$ and the rest according to Wadley, theoretical $\mathrm{LC}_{50}$ values were calculated from:

$$
\mathrm{E}=\frac{\mathrm{a}+\mathrm{b}+\mathrm{c}+\ldots+\mathrm{n}}{\frac{\mathrm{a}}{\mathrm{LC} C_{50}(\mathrm{a})}+\frac{\mathrm{b}}{\mathrm{LC} C_{50}(\mathrm{~b})}+\frac{\mathrm{c}}{\mathrm{LC}_{50}(\mathrm{c})}+\ldots+\frac{\mathrm{n}}{\mathrm{LC} C_{50}(\mathrm{n})}}
$$

where $\mathrm{E}, \mathrm{a}, \mathrm{b}, \mathrm{c} \ldots$... and $\mathrm{n}$ are as described above. The interaction between the observed and theoretical $\mathrm{LC}_{50}$ values (Equation (3)) was compared:

$$
R=\frac{\text { Expected } \mathrm{LC}_{50}}{\text { Observed } \mathrm{LC}_{50}}
$$

where $R$ represents synergistic interaction; the relationship between the constituents of the mixture is defined as either synergistic (when $R>1.5$ ), additive (1.5 $\geq R>0.5$ ), or antagonistic $(R \leq 0.5)$, based on this model.

\subsection{Stability of Essential Oils and Their Combinations at Different Time Intervals by Fourier Transform Infrared Spectroscopy (FTIR)}

The FTIR spectrum of the mixture of essential oils was performed on a Perkin Elmer Spectrum Version 10.4.2 model Frontier FTIR/NIR in the School of Engineering and Information Technology, Murdoch University. Functional groups were determined with the help of IR correlation charts. IR spectra were shown in the percentage of absorbance and the wave number region for FTIR analysis from $4000-400 \mathrm{~cm}^{-1}$. The FTIR software (version 2.3.1.5) and the OMNIC window with ATR cell were used for the analysis of the states of chemical bonding. The number of scans and their resolution were four with a resolution of $4 \mathrm{~cm}^{-1}$, and the detector MIR TGS (Waltham, Massachusetts, USA) was used. Beamsplitter OptKBr, Apodization strong, spectrum type spectrum, beam type ratio, phase correction magnitude, scan speed 0.2, IGram type Double, scan direction Combine JStop 8.94, IR-Laser Wavenumber 15798.00, Description DATR 1 bounce Diamond/KRS5.

The combinations of essential oil samples were prepared by mixing different binary types of essential oils in the ratio (1:1) and storing at three different temperatures, which were 15,25 , and $35^{\circ} \mathrm{C}$, for one, two, and three months. The FTIR was conducted after three months to determine the essential oil contents' stability of functional groups for the combination. A small drop of around $1 \mathrm{~mL}$ of the essential oil was placed on the plate 
and the spectrum run. The plates were thoroughly cleaned after each scan of an essential oil to prevent contamination of other samples and the diamond wiped with a tissue, then washed several times with methylene chloride, then ethanol, to remove the sample. The cleaned surface was clear and free from scratches.

\subsection{Data Analysis}

Mortality data from the essential oil elimination assay were subjected to analysis of variance (ANOVA) by using SPSS software version 24.0 (IBM Crop, Armonk, NY). Aphids were considered to be dead when no movement was detected by checking with a needle under a magnifying glass. Probit analysis was used to calculate the lethal dose (LC 50$)$ values that caused $50 \%$ mortality compared with the untreated aphids by using MS Chart software version 2016.12.07 [42]. Microsoft Office Excel version 2016 was used to analyze FTIR and GC-MS data.

\section{Conclusions}

In conclusion, the current study demonstrates the strong toxic effects against aphids using the essential oils of black pepper, eucalyptus, rosemary, and tea tree, and their binary combinations. They were found to have effective insecticidal properties in contact toxicity on GPA. The contact treatment of pure essential oil indicated that black pepper and tea tree essential oils were more effective than eucalyptus and rosemary essential oils on aphids at a high concentration after $24 \mathrm{~h}$. Essential oils are natural plant products containing a complex mixture of compounds and thus have multiple insecticidal or aphicidal properties. The essential oil mixtures showed their insecticidal effects on aphids and the interaction between the binary oils led to synergistic, additive effects. There was a synergistic effect between black pepper and tea tree, eucalyptus and tea tree, and rosemary and tea tree essential oils, while the other combinations of black pepper and eucalyptus, black pepper and rosemary, and eucalyptus and rosemary showed additive interactions. According to the FTIR analysis, essential oil combinations were stable between $15-35^{\circ} \mathrm{C}$ without affecting the properties of the oils. Therefore, we suggest that tested essential oil constituents in a pure state and in combinations should be screened as potential natural insecticides or be included in the chemical synthesis of a new type of pesticide, based on essential oils and their constituents.

Author Contributions: Conceptualization, Q.A., M.A. and Y.R.; Data curation, Q.A. and P.W.; Investigation, Q.A.; Methodology, Q.A., M.A., Y.R. and R.A.-O.; Project administration, Q.A., M.A. and Y.R.; Resources, Q.A., M.A. and Y.R.; Supervision, M.A. and Y.R.; Writing original draft: Q.A.; Writing-review and editing: Q.A., M.A., P.W. and Y.R. All authors have read and agreed to the published version of the manuscript.

Funding: This research received no external funding.

Institutional Review Board Statement: Not applicable.

Informed Consent Statement: Not applicable.

Data Availability Statement: Data are available from the authors on request.

Acknowledgments: We thank the Iraqi government for a Ph.D. scholarship and support for the first author. We also appreciate the support of Murdoch University Postharvest Biosecurity and Food Safety Laboratory, and technical support from James Newman and Bob Du.

Conflicts of Interest: The authors declare no conflict of interest.

Sample Availability: Samples of the compounds are not available from the authors.

\section{References}

1. Blackman, R.L.; Eastop, V.F. Aphids on the World's Crops: An. Identification and Information Guide; John Wiley \& Sons Ltd: Hoboken, NJ, USA, 2000.

2. Ben-Issa, R.; Gomez, L.; Gautier, H. Companion Plants for Aphid Pest Management. Insects 2017, 8, 112. [CrossRef] [PubMed] 
3. Omkar, G.; Surabhi, G. An improved method for rearing green peach aphid Myzus persicae (Sulzer). Int. J. Plant. Prot. 2013, 6, 492-493.

4. Favret, C.; Miller, G.L.; Aph, I.D. Identification Technology Program, CPHST, PPQ, APHIS, USDA. Fort Collins, CO. Available online: http:/ / AphID.AphidNet.org/ (accessed on 18 December 2020).

5. Sukh, D.; Opender, K.; Dev, S. Insecticides of Natural Origin; Apple Academic Press: Cambridge, MA, USA, 2017.

6. Isman, M.B. Botanical Insecticides, Deterrents, and Repellents In Modern Agriculture And An Increasingly Regulated World. Annu. Rev. Ėntomol. 2006, 51, 45-66. [CrossRef] [PubMed]

7. Moretti, M.D.L.; Sanna-Passino, G.; Demontis, S.; Bazzoni, E. Essential oil formulations useful as a new tool for insect pest control. AAPS Pharmscitech 2002, 3, 64-74. [CrossRef]

8. Regnault-Roger, C.; Philogène, B.J. Past and current prospects for the use of botanicals and plant allelochemicals in in-tegrated pest management. Pharm. Biol. 2008, 46, 41-52. [CrossRef]

9. Tunç, I.; Şahinkaya, S. Sensitivity of two greenhouse pests to vapours of essential oils. Èntomol. Exp. Et Appl. 1998, 86, 183-187. [CrossRef]

10. Bernard, C.B.; Krishanmurty, H.G.; Chauret, D.; Durst, T.; Philogène, B.J.R.; Sánchez-Vindas, P.; Hasbun, C.; Poveda, L.; Román, L.S.; Arnason, J.T. Insecticidal defenses of Piperaceae from the neotropics. J. Chem. Ecol. 1995, 21, 801-814. [CrossRef]

11. Scott, I.M.; Jensen, H.R.; Philogène, B.J.; Arnason, J.T. A review of Piper spp. (Piperaceae) phytochemistry, insecticidal ac-tivity and mode of action. Phytochem. Rev. 2008, 7, 65. [CrossRef]

12. Kérta, S.M.; Vincent, C.; Schmit, J.-P.; Ramaswamy, S.; Bélanger, A. Effect of various essential oils on Callosobruchus maculatus (F.)(Coleoptera: Bruchidae). J. Stored Prod. Res. 2000, 36, 355-364. [CrossRef]

13. Miresmailli, S.; Bradbury, R.; Isman, M.B. Comparative toxicity of Rosmarinus officinalis L. essential oil and blends of its major constituents against Tetranychus urticae Koch (Acari: Tetranychidae) on two different host plants. Pest. Manag. Sci. 2006, 62, 366-371. [CrossRef]

14. Choi, W.I.; Lee, S.G.; Park, H.M.; Ahn, Y.J. Toxicity of plant essential oils to Tetranychus urticae (Acari: Tetranychidae) and Phytoseiulus persimilis (Acari: Phytoseiidae). J. Econ. Entomol. 2004, 97, 553-558. [CrossRef]

15. Isman, M.B.; Miresmailli, S.; Machial, C. Commercial opportunities for pesticides based on plant essential oils in agriculture, industry and consumer products. Phytochem. Rev. 2011, 10, 197-204. [CrossRef]

16. Isman, M.B.; Wilson, J.A.; Bradbury, R. Insecticidal Activities of Commercial Rosemary Oils (Rosmarinus officinalis.) against Larvae of Pseudaletia unipuncta and Trichoplusia ni. in Relation to Their Chemical Compositions. Pharm. Biol. 2008, $46,82-87$. [CrossRef]

17. Batish, D.R.; Singh, H.P.; Kohli, R.K.; Kaur, S. Eucalyptus essential oil as a natural pesticide. For. Ecol. Manag. 2008, $256,2166-2174$. [CrossRef]

18. Koul, O.; Walia, S.; Dhaliwal, G. Essential oils as green pesticides: Potential and constraints. Biopestic. Int. 2008, 4, 63-84.

19. Hammer, K.; Carson, C.; Riley, T.; Nielsen, J. A review of the toxicity of Melaleuca alternifolia (tea tree) oil. Food Chem. Toxicol. 2006, 44, 616-625. [CrossRef]

20. Liao, M.; Xiao, J.J.; Zhou, L.J.; Yao, X.; Tang, F.; Hua, R.M.; Wu, X.W.; Cao, H.Q. Chemical composition, insecticidal and biochemical effects of Melaleuca alternifolia essential oil on the Helicoverpa armigera. J. Appl. Entomol. 2017, 141, 721-728. [CrossRef]

21. Cloyd, R.A.; Galle, C.L.; Keith, S.R.; Kalscheur, N.A.; Kemp, K.E. Effect of commercially available plant-derived essential oil products on arthropod pests. J. Econ. Ėntomol. 2009, 102, 1567-1579. [CrossRef]

22. Mann, R.S.; Tiwari, S.; Smoot, J.M.; Rouseff, R.L.; Stelinski, L.L. Repellency and toxicity of plant-based essential oils and their constituents against Diaphorina citri Kuwayama (Hemiptera: Psyllidae). J. Appl. Ėntomol. 2010, 136, 87-96. [CrossRef]

23. Isman, M.B. Plant essential oils for pest and disease management. Crop. Prot. 2000, 19, 603-608. [CrossRef]

24. Turek, C.; Stintzing, F.C. Impact of different storage conditions on the quality of selected essential oils. Food Res. Int. 2012, 46, 341-353. [CrossRef]

25. Farajzadeh, M.A.; Khoshmaram, L.; Nabil, A.A.A. Determination of pyrethroid pesticides residues in vegetable oils using liquidliquid extraction and dispersive liquid-liquid microextraction followed by gas chromatography-flame ionization detection. $J$. Food Compos. Anal. 2014, 34, 128-135. [CrossRef]

26. Tak, J.-H.; Jovel, E.; Isman, M.B. Comparative and synergistic activity of Rosmarinus officinalis L. essential oil constituents against the larvae and an ovarian cell line of the cabbage looper, Trichoplusia ni (Lepidoptera: Noctuidae). Pest. Manag. Sci. 2016, 72, 474-480. [CrossRef] [PubMed]

27. Coronado-Puchau, M.; Saa, L.; Grzelczak, M.; Pavlov, V.; Liz-Marzán, L.M. Enzymatic modulation of gold nanorod growth and application to nerve gas detection. Nano Today 2013, 8, 461-468. [CrossRef]

28. Liao, M.; Xiao, J.-J.; Zhou, L.-J.; Liu, Y.; Wu, X.-W.; Hua, R.-M.; Wang, G.-R.; Cao, H.-Q. Insecticidal Activity of Melaleuca alternifolia Essential Oil and RNA-Seq Analysis of Sitophilus zeamais Transcriptome in Response to Oil Fumigation. PLoS ONE 2016, 11, e0167748. [CrossRef]

29. Carson, C.F.; Hammer, K.A. Chemistry and Bioactivity of Essential Oils. Lipids Essent. Oils Antimicrob. Agents 2010, 203-238. [CrossRef]

30. Yazdgerdian, A.R.; Akhtar, Y.; Isman, M.B. Insecticidal effects of essential oils against woolly beech aphid, Phyllaphis fagi (Hemiptera: Aphididae) and rice weevil, Sitophilus oryzae (Coleoptera: Curculionidae). J. Entomol. Zool. Stud. $2015,3,265-271$. 
31. Hollingsworth, R.G. Limonene, a citrus extract, for control of mealybugs and scale insects. J. Econ. Èntomol. 2005, 98, 772-779. [CrossRef]

32. Liška, A.; Rozman, V.; Kalinović, I.; Ivezić, M.; Baličević, R. Contact and fumigant activity of 1, 8-cineole, eugenol and camphor against Tribolium castaneum (Herbst). 10th Inter. Work. Conf. Stored Prod. Prot. 2010, 425, 716.

33. Abtew, A.B.; Subramanian, S.; Cheseto, X.; Kreiter, S.; Garzia, G.T.; Martin, T. Repellency of Plant Extracts against the Legume Flower Thrips Megalurothrips sjostedti (Thysanoptera: Thripidae). Insects 2015, 6, 608-625. [CrossRef]

34. Kasmi, A.; Hammami, M.; Raoelison, E.G.; Abderrabba, M.; Bouajila, J.; Ducamp, C. Chemical Composition and Behavioral Effects of Five Plant Essential Oils on the Green Pea Aphid Acyrthosiphon pisum (Harris) (Homoptera: Aphididae). Chem. Biodivers. 2017, 14, e1600464. [CrossRef] [PubMed]

35. Hori, M. Antifeeding, settling inhibitory and toxic activities of labiate essential oils against the green peach aphid, Myzus persicae (Sulzer) (Homoptera: Aphididae). Appl. Èntomol. Zool. 1999, 34, 113-118. [CrossRef]

36. Digilio, M.C.; Mancini, E.; Voto, E.; De Feo, V. Insecticide activity of Mediterranean essential oils. J. Plant Interact. 2008, 3, 17-23. [CrossRef]

37. Tomova, B.S.; Waterhouse, J.S.; Doberski, J. The effect of fractionated Tagetes oil volatiles on aphid reproduction. Èntomol. Exp. Appl. 2005, 115, 153-159. [CrossRef]

38. Görür, G.; Abdullah, M.; Işik, M. Insecticidal activity of the Thymus, Veronica and Agrimonia's essential oils against the cabbage aphid, Brevicoryne brassicae. Acta Phytopathol. Et Entomol. Hung. 2008, 43, 201-208. [CrossRef]

39. Faraone, N.; Hillier, N.K.; Cutler, G.C. Plant Essential Oils Synergize and Antagonize Toxicity of Different Conventional Insecticides against Myzus persicae (Hemiptera: Aphididae). PLoS ONE 2015, 10, e0127774. [CrossRef] [PubMed]

40. Ahmed, Q.H. Evaluation of Efficacy of Fumigants and Natural Product Extracts For. Management of Springtail Hypogastrura Vernalis (Collembola: Hypogastruridae) and Green Peach Aphid Myzus Persicae (Hemiptera: Aphididae). Doctoral Dissertation, Murdoch University, Perth, Australia, 2018.

41. Pavela, R. Acute and synergistic effects of monoterpenoid essential oil compounds on the larvae of Spodoptera littoralis. J. Biopestic. 2010, 3, 573-578.

42. Chi, H. Probit-MS Chart: A Computer Program for Probit Analysis. Available online: http://140.120.197.173/Ecology/2017 (accessed on 10 May 2021). 